\title{
Characteristics of War Threats (Causes, Effects and Ways to Counteract Them)
}

\author{
Dr Jan Pilżys" \\ University of Szczecin, Department of Humanities, Institute of Political Science and European Studies, Poland \\ *Corresponding Author: Dr Jan Pilizys, University of Szczecin, Department of Humanities, Institute of \\ Political Science and European Studies, Poland
}

\begin{abstract}
The author's task is to show that society and the achievements of civilization are the basic point of reference to the phenomenon of war. They have a strong impact on contemporary political, social and military realities. They can start, deepen or end any bloody conflict. Each of them is very complex and at a given moment in time in many parts of the world multiplies victims and causes huge material damage. According to the author, the emergence of new conflicts and the persistence of old ones depend on several conditions, i.e.: disproportions and imperfections in the potential of states, inability to exercise effective control over their territory and population by the rulers, ignorance of the rulers with the sovereign's voice, functioning of bad international law, mixing of cultures and religions - resulting in the disintegration of states and their civilizations.

The escalation of conflicts causes them to turn into a war that engages others, spreading destruction, fear and anxiety of an uncertain future. According to the author, the helplessness of companies, including state and world institutions, does not mean the disappearance of survival. Therefore, the author hopes that with his reflections, observations on the nature of war and its military threats he will contribute to a change in the way decision-makers think about war, which is not the final solution to problems.
\end{abstract}

\section{About THE ESSENCE OF WAR}

According to the author, war and its causes should be discussed and written, showing the interested people problems and ways to solve them. It must be made clear that the enormity of the contemporary dangers is the result of ill-considered human activity. Therefore, it is necessary to control them. It is necessary to prepare a global opinion against any manipulation of propaganda - that we are threatened with something, and that there is therefore a need for the militarisation of the state and the transfer of huge sums of money to military programmes. Such actions do not lead to anything good.

There is now a visible tendency on the part of European countries to increase their armed forces. More and more financial resources are being used for this purpose. This leads to excessive impoverishment of budgets and thus of societies. The question should be asked: Is this necessary?

In Europe, almost every country belongs to an alliance ${ }^{1}$, at least one or more of them has nuclear weapons. At present, they are a protective umbrella for states which do not possess these weapons. And here there are other questions: will this country use these weapons against a state that is threatening the alliance, or will it not hesitate? We know from history that the allies did not abide by the agreements, what then - the attacked state must defend itself by waiting for someone to come to its aid.

Hence, the conclusion that every state belonging to an alliance should have its own defense system, including armed forces ready for war. The question is just what kind of war - a conventional war, a conventional war with tactical nuclear weapons, or a nuclear war - it is? Are they probable in today's conditions? Will it be possible for the aggressor and the defender to achieve the goals of the war?

\footnotetext{
${ }^{1}$ B. Chocha, J. Kaczmarek, War and war doctrine. Selected issues, Warsaw 1980, p.82-91 According to the authors of the publication "The word "coalition" contains the concept of strength and at the same time an inherent concept of weakness. It is a very complex phenomenon, which is caused by differences between the coalition's partners in terms of war-economic potential and actual political and ideological goals. These causes form weaknesses and, consequently, discrepancies in the nature and ways of preparing and conducting war.
} 
What will be the consequences for the participating countries? Some of these questions cannot be answered unambiguously.

Since time immemorial, the issue of peace and war for nations has been a matter of life or death. To this day, wars are an important part of history of warfare, especially war science and art of war, which shape the image of modern warfare and war in its entirety. They bring new experiences that can be used by strategists in the next wars. Therefore, there is a need to refer to the statements of the most eminent minds of past centuries and epochs on this issue.

It is impossible not to agree that war is the most terrible disaster and the greatest misdeed. Wars, as genocide, will be counted among the extraordinary atrocities that degrade and violate human nature, that insult a country and an epoch that is stained with the greatest of crimes ${ }^{2}$. According to Frederick Hegel and Clausewitz, war is a political act, an instrument of politics that wants to resolve a conflict through the use of armed force ${ }^{3}$. Are politicians to blame most for each war? Can they not see that it does not pay to abuse force. Afghanistan, Georgia, Ukraine, Syria, Libya and South Sudan are examples. Abuse of force leads to poverty and destruction of the population, material legacy and world heritage sites ${ }^{4}$. In many cases, genocide, crimes against humanity or war crimes are done, not only by the aggressor but also by internal forces. There have been about 160 wars and internal conflicts between 1945 and today, some of which are still ongoing. They have claimed tens of millions of lives ${ }^{5}$. Such actions fall under the jurisdiction of the International Court of Justice in The Hague. According to the author, the United Nations Security Council is doing little about this. What is the European Court of Human Rights doing? What is the justification for this state of affairs?

It is likely that the law and order in the international community have been shaken and are drifting towards a 'world war'. There are many indications that international law is losing its relevance in the era of the United Nations and other organizations e.g. Organization for Security and Cooperation in Europe and of the African Union, it is shaky and unstable. It lacks a binder - authority, a joint force (international police) to enforce its observance ${ }^{6}$. The member states of each of these organizations are to a large extent judges in their own cases ${ }^{7}$.

I agree with Michael Walzer that 'lawyers have created a paper world that is fundamentally different from the world we live in' ${ }^{\prime}$. Its construction breaks and threatens to disrupt the entire structure, and only because one of the countries breaks out defending its own interests. It is therefore our duty to organize a new legal system prohibiting such practices, in particular, deterring regimes and global terrorism ${ }^{9}$. These must be rapid measures to prevent the spread of the accumulating problems of states without the terrible devastation of war. Creation of a new system of anti-war law - hindering or legally preventing the outbreak of war $^{10}$.

From the above it can be concluded, that war is one of the oldest social phenomena known to humanity. Despite the international ban on the use of force or the threat thereof, it remains an important instrument for the implementation of foreign policy. A whole generation of researchers

\footnotetext{
${ }^{2}$ J. G. Bloch, The future war in technical, economic and political terms, Warsaw 2005, p. 80.

${ }^{3}$ Z. Kuźnar, K. Barczyk, The phenomenon of war from the point of view of G.F. Hegel's dialectic philosophy, [in:] M. Bodziany (ed.) Society and war. The face of security in the twentieth and twenty-first centuries, Wrocław 2016, p. 385-387; B. Balce-rowicz, About peace and war. Between the essay and the treatise, Warsaw 2013, p. 83, A. Makowski, Marine wars - methodological problems, [w:] A. Aksamitowski, M. Franz (ed.), From the history of the maritime wars. Studies and sketches, Oświęcim 2015, p. 14;

${ }^{4}$ J. Pilżys, System of security of monuments and national heritage of the Republic of Poland, [in:] J. Piątek, R. Podgórzańska (ed.) Selected aspects of security, Volume I, Szczecin 2007, p. 251.

${ }^{5}$ Look wider: A. Toffler, H. Toffler, War and anti-war, how to survive on the threshold of the 21st century, Warsaw 1997.

${ }^{6}$ J. S. jr., Nye, International Conflicts. Introduction to Theory and History, Warsaw 2009. p. 24, T. Jemioło, T. Kubaczyk, M. Preus, Arms of mass destruction in international law - selected problems, Warsaw 2004, p. 17,

${ }^{7}$ L. Chojnowski, International Security. Institutional and organizational aspects, Słupsk 2017, p. 38.

${ }^{8}$ M. Walzer, Just and unjust wars, Warsaw 2010, p. 27.

${ }^{9}$ W. Zubrzycki, The threat of terrorism to Europe. Selected topics, [in:] A. Aksamitowski, S. Bylina, M. Cupryjak (ed.), Contemporary terrorism. Dimensions of action and effects, Szczecin 2018, p. 19, K. Zawadzka, Growing influence and threats of Islam on Western European civilisation in the 21st century, A. Aksamitowski, S. Bylina, M. Cupryjak (ed.), Contemporary terrorism..., p. 101.

${ }^{10}$ W. Góralczyk, S. Sawicki, Public International Law in outline, Warsaw 2013, p. 354.
} 
from various fields of science tried to explain the nature of wars and their causes. This concept focuses both on terror and on the feeling of triumph. On the one hand, it signals cruelty, death and loss, and on the other hand, it encompasses joy, satisfaction with the victory and defeat of the opponent ${ }^{11}$. But as a result, it destroys everything that man values the most - human life.

According to the author, it is necessary to rigorously oppose those who claim that war is inevitable and necessary, that it is considered to be one of the rules of human development. It must not be allowed to be the result of chance, erroneous decisions or a desire on the part of 'some' politician (Putin or Tramp) to gain and maintain power. We must resist the blind obedience to incompetent politicians, the military and capitalists, who are ruining the social justice of their own people and of the world, by dividing the population, putting them one on top of the other, pushing them to fight in the name of their own interests. Therefore, there must be forces in control over sinister propaganda to ensure that peace is maintained in the world.

\section{Characteristics of Military Threats}

After considering the very essence of war, its causes (reasons) I am going to try to carry out a characterization of war threats and their influence on the society.

Today, it is difficult to estimate the amount of expected losses after the war has started, during the war and after it has ended. However, given the changes in the war tactics, the force of the weapons and the location of the military operations, we may be tempted to ask ourselves what it means to be at risk and what the consequences of the use of fighting measures in an armed conflict are.

In security dictionaries and lexicons, the term "threat" itself is most often defined as a crisis situation in which there is a probability of an event occurring which is dangerous for the life and health of a person, their property and the environment in which they live. Every now and then, driven by the forces of nature, ill-considered human activity and aggressive policies of another country. It can cause a direct crisis leading to conflict (clash of contradictory aspirations, incompatibilities of interests, views), which can turn into a fight of one against the other.

The fight is not only about achieving the desired values, but also about neutralizing, reducing or eliminating one of the parties. This means that a threat is a destructive value, causing an undesirable state to man, nation, state or group of states ${ }^{12}$.

What, then, is military threat and its origin? "Generally speaking, it is understood as a potential or existing danger of the use of armed violence, directly or indirectly, against national values and interests" ${ }^{\prime \prime}$. Its source is the military potential of countries involved in armed conflict, including the destructive use of military force on a tactical, operational and strategic scale to achieve the objectives of war. It is the ultimate means of physical coercion to impose one's will on another. It follows that it can be preceded by actions which do not cause direct human losses. So we will have a state of no war called a crisis. However, its extent can lead to war through: recognition and installation of a malicious agent network, actions compromising and disorganizing the activities of the state, provocation of conflicts, intimidation of authorities and society, blocking of areas and objects important for the security and defense of the state, sabotage and diversion, acts of terror, imposing one's own will leading to the incapacitation of the state.

For the purpose of this article, a catalogue of military threats will be presented, as well as their brief characteristics in terms of their causes, structure, what they may concern and their consequences, and what the actions taken to reduce losses should be.

The basic tool for the characterization of threats, including their assessment, is the analysis of the state of existing and potential threats, which have already occurred in armed conflicts and potential conflicts, which may occur in the territory of a given territorial unit of a country ${ }^{14}$. The aim of the

${ }^{11}$ F. Ryszka, Politics and war, colloquial awareness and 20th century theories, State Publishing Institute, Warsaw 1975, B. Miśkiewicz, War as the subject of historical research, [in:] K. Olejnik (ed.), War as a subject of historical research, Toruń 2006.

12 J. Pilżys, Lexicon of economic safety, Szczecin 2011, p. 177-181.

${ }^{13}$ R. Jakubczak, J. Flis (ed.), National security of Poland in the 21 st century. Challenges and strategies, Warsaw 2006, p. 105.

${ }^{14}$ M. Enerlich, J. Wojtal, M. Milewicz (ed.), Protection of persons and property, Toruń 2003, p. 493 According to the authors of the publication, threat analysis means: dissection, division into factors, elements, examination 
analysis is to evaluate point, linear and surface objects in terms of potential threats ${ }^{15}$. It is carried out on the basis of detailed information on facilities (hospitals, sanatoriums, workplaces, dams, residential buildings, petrol stations, expressways, rivers, lakes, forests and others), their vulnerability and, as a result, how to prevent secondary threats, i.e. effects on the area of the facility, at the time of its destruction and afterwards. Most often, the analysis is a new combination of statistical, descriptive and graphical analysis ${ }^{16}$. Each of them is partially used in the initial and in-depth analysis. It is important that the necessary information can be properly classified and demonstrated for the individual components of the hazard and, consequently, for its entirety, that temporal-spatial and time-cause relationships can be demonstrated. They are to contribute to the forecasting of threats and drawing conclusions regarding the implementation of anti-crisis tasks, indicating the goal, time, place, means, methods and persons implementing them ${ }^{17}$.

For centuries, war has been changing with the development of civilization. Today, wars (armed conflicts) are part of our reality. They are conducted within states and with external enemies. There has been an enormous evolution of weapons understood as arming the armed forces (armed groups) with means of destruction with kinetic, chemical, biological, nuclear energy and weapons of information. A weapon that can destroy (overpower) any target on the globe with its destructive power and reach, thereby destroying what man values most - life. As a result, a modern battlefield of opposing parties is created. Each of them uses what is best, starting with the soldier and his equipment through patriotic calls - the homeland is in danger - to arms. Depending on the momentum of action on earth and water, in the air and in space, i.e. inflicting losses and gaining benefits, it can achieve tactical, operational and strategic significance.

During warfare, the enemy will mostly use weapons on military groups, more important centers of public administration, including critical infrastructure important for the fighting state. These will be mostly rocket-aircraft, artillery and landing strikes with the use of conventional combat components. On the other hand, aeromobile, landing and special-purpose troops will have to maintain more important facilities and open crossings for typically land-based troops.

The most vulnerable facilities will be plants producing weapons and equipment for the army, installations and devices supplying them with energy resources, fuels and energy, communication facilities, food, water, transport, media, etc.. The attack on those not only causes loss of property, but also the population operating the equipment in these facilities, as well as people living directly in their vicinity. An additional threat may be the activities of diversion and reconnaissance groups, focused on destroying everything that may disorganize the activities of the army and civil population of the opposite side.

With the use of each of these weapons, and in particular weapons of mass destruction, there will be more deaths than injuries. Depending on the crisis situation, medical, social and living assistance and logistical support will not be provided in time everywhere and to everyone. Especially for civilians inside and outside the war zone.

One of the main criteria for assessing the use of these weapons is their effectiveness, as measured by their degree of destruction, i.e. the achievement of a political, strategic, operational or tactical objective. An important element discussed in the next chapter is the protection of the population with its goods and environment in the event of the consequences of military threats ${ }^{18}$.

of particular features, properties of a phenomenon or object. In this sense, it can be a method and a tool to investigate the facts and relationships related to broadly understood security. The most effective forms of combating threats include: detection and recognition of a threat and creation of effective protection (securing) of persons and objects in various situations. In their view, protection is achieved by means of direct physical protection and by means of technical protection measures.

15 D. Wróblewski, Concept of a long-term rescue system, Józefów 2016, M. Biniak-Pieróg, Z. Zamiar, Organization of rescue systems, Wrocław 2013.

${ }^{16}$ Regulation of the Minister of Internal Affairs and Administration of 18 February 2011 on detailed rules of organization of the national rescue and firefighting system (Journal of Laws No. 46, item 239), Appendix 1: The appendix presents methods of threat assessment in the area of the county and the province.

${ }^{17}$ W. Feluch, Flood risk forecasting, [in:] Security management at the local level, Warsaw 2012.

${ }^{18}$ W. Kitler, Protection of population, [in:] W. Kitler (ed.) Non-military civil defense in national defense of the Third Republic of Poland, Warsaw 2001, p. 92. 


\section{WEAPONS OF MASS DESTRUCTION}

At present, the threats of war include weapons of mass destruction, including: nuclear, chemical and biological weapons. The first is associated by the international community as "horror", "nuclear deterrence", i.e. the possibility for one of the nuclear-weapon powers to exert pressure on state governments and public opinion for political, economic and military gain. From the military point of view, these weapons are considered as a retaliatory measure or as a last resort in the fight against an enemy. It is the most destructive means of fighting that man could have created so far.

At present and in the future, it is to be expected that there will be nuclear blackmails or limited hybrid conflicts (using conventional weapons and nuclear means with reduced impact) between states. Its arsenal is being expanded, thus increasing the potential risk of a nuclear disaster.

The imperatives and prohibitions contained in international agreements relating to its production, distribution and dissemination are so ineffective that they broken at any time without any 'consequences'. No provision of international law explicitly prohibits the use of nuclear weapons, but it greatly limits their use in the future to such an extent that their retention would be useless. Before this happens, it is now effectively stopping the aggressor from starting a conventional or nuclear war. Hence, the conclusion that with such a large nuclear threat, the result of our equation is a positive one, i.e. in favour of nuclear weapons. If it had not been for that, would the political and military situation of the countries in Europe be as it is today? Maybe I am wrong and its use is only a matter of time. There are therefore a number of questions that need to be asked: Why is it so dangerous? How to defend oneself against it?

\subsection{Nuclear Weapons (of Mass Destruction)}

They are among the most dangerous destructive weapons mankind has ever been able to construct. In addition to radioactive contamination of humans and the environment, it causes damage to critical infrastructure. It is produced in the form of aerial bombs (atomic, nuclear, thermonuclear, hydrogen, neutron), rocket warheads, artillery missiles, torpedoes or nuclear fugases. The destructive and radiating action of a nuclear explosion is thousands of times greater than that of the heaviest demolition bombs. It is based on the use of nuclear energy, which is released during nuclear explosive reactions. The explosion is accompanied by a shock wave, thermal and permeable radiation, radioactive contamination and electromagnetic impulse ${ }^{19}$.

The shock wave is the main factor of damage, destroying everything along its way from the center of the explosion $(1500 \mathrm{~km} / \mathrm{h}$ and more). High wave propagation velocity and high pressure of $0.5-2.0$ $\mathrm{kG} / \mathrm{cm} 2$ can cause mechanical damage to the body and internal organs and even death. The amount of damage will depend on the explosion power, the type of explosion and the zone of destruction of the weapon used. Moreover, the magnitude of the shock will depend whether humans are in the open or covered area.

Thermal agent is a huge explosion temperature causing fires in the raving-zone and human burns of 1st, 2nd, 3rd and 4th degree. The first stage is characterized by superficial skin burns, the second by blistering, the third by wounds, the fourth by carbonization of the skin and subcutaneous tissue. Each stage of injury depends on the magnitude of the thermal pulse acting on a human being, the size of the burnt body surface and its location. What is also important is the type of explosion, its strength, zone and place of destruction.

In living organisms, permeable radiation causes radiation disease or even immediate death. A distinction is made between three levels of radiation disease: I. after receiving a dose of 100 to 200 roentgens, II of 200 to 300 and IV of 300 to 500 roentgens. The disease is generally not present after less than 100 roentgens. Regardless of the degree of radiation, in the initial period of the disease, the person does not feel any ailments. However, with the elapse of time of its development and doses of irradiation, dangerous symptoms of radiation disease begin to appear in the human body, including headaches, nausea combined with vomiting, weakening of the body. The most dangerous is the third stage of the radiation disease, characterized by a very severe course, which in most cases ends in death.

${ }^{19}$ T. Jemioło, T. Kubaczyk, M. Preus, Weapons of mass destruction..., p. 13. 
The radioactive contamination of the environment is caused by the radioactive dust that emerges after the nuclear explosion, and which contaminates everything it encounters along its way when it moves with airborne particles. In case of getting into the skin of a person and inside their body, it will cause radiation disease.

It follows from the above that the nature and extent of the human injury during a nuclear explosion and the degree of destruction of various facilities will depend on the strength and type of the explosion, the conditions of deployment of troops and civilians, the degree of preparation for defense against the effects of its use, weather conditions, terrain, vegetation, season, atmospheric conditions. The exposure of the population and the environment to the agents of concern will be combined due to the simultaneous action of all or several agents of concern. It will cause ${ }^{20}$ : large areas of damage, especially to critical infrastructure, homelessness, radioactive contamination of land, water, food, feed, radiation disease, large numbers of deaths and injuries, destruction of magnetic information media, radio interference, fires. In addition, nuclear power plants abroad are a major problem. Destroying them during military operations will result in radioactive contamination from atmospheric air movement, flowing river waters and migration of people and wildlife.

The question is, at the moment, whether there are ways to save people from the devastating effects of a nuclear explosion and to rebuild critical infrastructure in a contaminated area. According to the author, the possibilities of defense against them are minimal or even impossible in the case of mass destruction. Knowing that no country will get rid of it, what needs to be done to survive. Currently, barriers similar to missile defense shields are being created with a poor effect - something like umbrellas to protect the most important strategic areas of countries from their destructive power. This is to destroy the carriers on their way to the target. If this fails, i.e. one of the many missiles hits its target, the attacked state must be prepared to provide assistance to the affected population in conditions of mass destruction. Therefore, there is a need to prepare the potential of health care services, rescue units, awareness and familiarization of the population with the combat properties of the factors of nuclear weapons destruction and how and with what means to protect oneself against them. In particular, this should apply to communities living next to facilities important for the security and defense of the attacked state. They will be main targets of nuclear weapons attacks and thus of the mass destruction of everything around them.

\subsection{Chemical Weapons}

They are poisonous agents whose damaging action results from the use of highly toxic chemical compounds. It is divided into the following agents ${ }^{21}$ : suffocating (e.g. Cyclone B), steaming (e.g. mustard gas (iperite), pertussing (e.g. phosgene), paralytic (e.g. taboos, sarin, cyclosarine, somane), hallucinogenic and anaesthetic (e.g. LSD).

The 1992 disarmament conference drew up and adopted a document in the form of a convention introducing a total ban on the production and use of chemical weapons worldwide ${ }^{22}$. According to its policy, these weapons were to be destroyed until 2007. That period shall be extended from time to time $^{23}$. For what purpose? What are the contraindications in achieving it. It can therefore be concluded that these weapons may still be in stockpiles in some countries around the world. In its arsenal, they can possess chemicals intended for chemical contamination of air, soil and water, and as a consequence poisoning of people, animals and food, and destruction of vegetation. It may be in a volatile, liquid or solid form.

Their use will cause significant losses in people and animals. Both paralyse the nervous system, causing temporary blindness, deafness, paralysis, nausea or vomiting, severe burns to the skin, eyes or

${ }^{20}$ Data regarding the division of threats and their characteristics were taken from the provincial crisis management plan - Łódź and the municipal crisis management plan - Sieradz, [in:] http: // www. lodzkie.eu/data/other/wpzk04. 2012.pdf [read: September 26, 2012]; see also: http://www.sieradz.eu/sites/ default / files / plik / uzytkownicy / bbo / urban crisis management_plan 2012-no pelnakopia0.pdf [read: 31 January 2013].

${ }^{21}$ L. Chojnowski, International security. International and organizational aspects, Słupsk 2017, p. 106.

${ }^{22}$ Disarmament, [in:] http://www.unic.un.org.pl/rozbrojenie/konferencja_disqualnic.php [accessed on April 5, 2018].

${ }^{23}$ S. Śladkowski, Threats of the battlefield, [in:] Defense against weapons of mass destruction, Warsaw 2007, p. 13. 
lungs, making breathing difficult ${ }^{24}$. They may be carried in containers by aircraft or ammunition and equipment specially constructed for this purpose.

In an armed conflict, not only people will suffer, but also critical infrastructure of public, financial, research, social, information, health, rescue, transport, water and food supply administration. In particular, construction works, equipment, installations and services essential for the security and defense of the State and its citizens. These include ${ }^{25}$ : ports, roads, bridges, hospitals, rescue centers, fuel depots, production facilities, railway lines, power lines, gas pipelines, waterworks, oil pipelines, telephone lines. During the war they will need special protection from company services and rescue units associated in the National Rescue and Fire Extinguishing System (KSR-G) ${ }^{26}$. The State Fire Service plays a leading role in its structures, supported by gas, energy, water supply, railway, road, water, sea, mountain rescue services and, depending on needs, other services, guards and state institutions. In addition to the forces and measures already mentioned, civil protection forces and measures, the military, the police and social and economic support actors will be involved in rescue operations $^{27}$.

As I said before, these will be measures to ensure the stability and peace of the population in war zones. To protect them from tactical nuclear as well as conventional impact, resulting in massive loss of population and destruction of critical infrastructure of the country, including its systems, networks, facilities and equipment ${ }^{28}$. The most dangerous of these would be chemical plants, armaments plants and water damming plants. Destruction and its consequences will be similar to those of warfare weapons used on a battlefield.

\subsubsection{Impacts on the Chemical Industry}

Destruction or damage of transports of Toxic Industrial Agents, plants using chemical compounds in technological processes may cause toxic industrial contamination of people and the environment. The scale of toxicity will be very high. According to the United Nations Economic Commission for Europe, the most dangerous chemical substances are those that have the following effect:

- suffocating: chlorine, phosgene, chloropicrin,

- generally poisonous: nitric oxide, acrylonitrile, nitric acid, sulphur dioxide, hydrofluoride,

- harmful to the transmission and sending of nervous impulse (neutropic poisons): carbon disulphide, lead tetraethyl, organophosphorus compounds,

- suffocating and neutropic: ammonia, dimethylhydrazine,

- interfering in the exchange of substances: dioxin and polychlorinated benzofuran as well as metabolic poisons: ethylene oxide and dichloroethane,

- Some of them, if released during an attack on an object that produces soap or washing powder, or carrying components for its production, may cause, apart from toxic effects, other hazards related to the risk of explosions, fires and poisonous products that may occur during the attack. In this case, the threat of contamination has a continuous character, it can reach a special dimension, i.e. an environmental disaster of great significance not only for the local communities, but also for the region or the whole country.

\footnotetext{
${ }^{24}$ T. Jemioło, T. Kubaczyk, M. Preus, Weapon of mass destruction ..., p. 15.

${ }^{25}$ Crisis Management Act 2007, Section 3.

${ }^{26}$ Regulation of the Minister of Internal Affairs and Administration of 18 February 2011 on detailed rules of organization of the national rescue and firefighting system (Journal of Laws of 2011 No 46, item 239).

${ }^{27}$ White book on the National Security of the Republic of Poland, Warsaw 2013, p. 38.

${ }^{28}$ J. Pilżys, Selected aspects of threat by toxic industrial agents, [in:] K. Chwesiuk (ed.), Crisis management in land transport in Pomerania, Koszalin 2003, pp. 108-109. Poland, although it is an average industrialized European country, has a significant number of chemical plants. The range and size of their production clearly indicates that in technological processes large amounts of chemical compounds treated as toxic industrial chemicals are used. There are about 250 large and medium-sized chemical plants in Poland, of which about 35 are included in the high-risk group. Distribution of chemical plants across the country is very disadvantageous. Most of them were built in areas of high population density, at small distances from large urban agglomerations and on the banks of the main Polish rivers. Another threat to our country is the location of some chemical plants of neighbors near our borders.
} 
In the event of damage to a chemical plant, it is the duty of each emergency management center to have a response (rescue) plan to a chemical emergency, including an effective system: alerting and informing the population about the threat, communication between the heads of emergency management teams and the heads of specific services and institutions or ad hoc civilian-military anticrisis headquarters, acquiring, processing and transferring information, coordinating operations and managing forces and resources, evacuating the population from the zones of contamination, eliminating the effects of damage in the contaminated areas.

Strikes at the armaments industry will result in an explosion of the bombs, rockets, artillery missiles, firearms and chemical agents present there. This attack will result in irreversible damage to people and the environment. That is to say those who work in these facilities and those who live around them. The critical infrastructure of the assigned area will also be endangered, causing the disorganisation of the life of the society. All this means that the problem of contamination exists and is so important that it cannot be underestimated.

Strikes at water storage facilities results: flooded towns and villages, damage to crops and forests, irreversible human and animal losses, possible epidemics and epizootic diseases.

\subsection{Biological Weapons}

They are very difficult to detect and combat. From the definitions given, it can be assumed that these are "living organisms (bacteria, viruses, protozoa, fungi) and the substances they produce, as well as certain higher organisms (infected insects, rodents), including their means of transmission and propagation" 29 . Their use can cause human epidemics, animal epizootic diseases, plant epiphytoses, zoonoses, poisoning, health damage and human and animal losses.

Since 1972, the research, production, storage and acquisition of biological and toxin weapons has been prohibited ${ }^{30}$. However, there is still uncertainty among states that these weapons have been completely destroyed and, worst of all, have entered the hands of terrorists. Therefore, with so much uncertainty, it can be assumed that it can be used in the near future. Its use before and during the fight will be aimed at reducing the personal potential of the attacked country, disrupting the mobilization process, displacing and deploying the evacuees, and impede logistic stocks ${ }^{31}$. Its use is very difficult to detect and therefore it is difficult to take timely corrective measures.

At this point, one should ask the question whether we are prepared for such an attack. In order to respond to such a question, the author assessed the legal acts and on their basis analyzed the structure of civil-military systems and the forces and measures responsible for preventing their occurrence, preparing to take control over them by means of planned actions, reacting in case of their occurrence, and reconstructing or restoring the situation from before the attack with the use of the warfare agent.

Due to the existing threats for the time of peace and "war", the Act on infectious diseases and infections was developed and implemented ${ }^{32}$. It lays down 'rules and procedures for the prevention and control of infectious diseases and human infections, in particular for identifying and following epidemiological situations and for taking preventive and anti-epidemic action to inactivate the source of infection and cross the routes of dissemination, including immunization of susceptible persons ${ }^{33}$. This is where one can find the subsystem for managing the system to combat this risk.

The prevention and control of the diseases listed in Annex 1 to the Act is the responsibility of the minister competent for health, in cooperation with $^{34}$ : ministers of internal affairs, national defense, justice, agriculture, environment, and with the Sanitary Inspection authorities (general, provincial,

\footnotetext{
${ }^{29}$ Ibidem, p. 14, Defense against Weapons of Mass Destruction, Warsaw 2007, p. 11.

${ }^{30}$ The International Convention on the Prohibition of the Development, Production, Stockpiling and Acquisition of Biological and Toxin Weapons, which entered into force on 26 March 1975, has been ratified by 144 countries to date. Poland ratified the Convention on 11 December 1972, Defense against Weapons of Mass Destruction, AON, Faculty of Land Forces, Warsaw 2007, pp. 11-12.

${ }^{31}$ Defense against Weapons of Mass Destruction ..., p. 12.

${ }^{32}$ Act of 6 September 2008 on the prevention and control of infections and infectious diseases in humans (Journal of Laws No. 234, item 1570).

${ }^{33}$ Ibidem, art. 1.

${ }^{34}$ See also: P. Kępka, Bioterrorism. Poland in the face of the Use of Biological Weapons, Warsaw 2009, pp. 71135.
} 
district health inspector), the Veterinary Inspectorate, the National Health Fund, managers of health care institutions, healthcare providers - persons performing medical professions outside health care institutions, managers of production plants, service and commercial facilities. In addition, the Minister of Health cooperates with the World Health Organization as appropriate.

In order to identify infectious diseases (biological hazard factors), the following have been established at the national level:

- the sanitary-epidemiological board an advisory and opinion-forming body of the chief health inspector,

- border sanitary inspectors,

- inspector for chemical substances,

- national reference centers and research and development centers

- organisational units of the sanitary-epidemiological division of the military health service, including preventive medicine centers,

- provincial and county sanitary-epidemiological stations,

- laboratories carrying out microbiological, serological and molecular tests,

- doctors, paramedics, nurses, midwives and school hygienists,

- the prosecution and the judiciary.

The institutions listed above form a surveillance network ensuring the monitoring of the epidemiological situation of communicable diseases, detection and early notification of the epidemic threat in the country. This network creates a system of defense against infectious diseases and infections and detection of biological pathogens.

In connection with the threat under consideration, the National System for Detecting Contaminants and Alerts has been established in Poland. Its aim is to prevent the effects of natural disasters, technical, biological, radioactive accidents and act of terrorism ${ }^{35}$. The activity of the system is supervised by the Minister of National Defense, who cooperates with the ministers of: internal affairs and administration, environment, health and infrastructure. The system consists of:

- the system for detecting contamination of the Armed Forces of the Republic of Poland,

- networks and systems of epidemiological surveillance and control of communicable diseases in the country and national contact points for international systems of surveillance of health or life threats to large groups of people,

- a system of early detection stations for radioactive contamination and facilities measuring radioactive contamination, coordinated by the President of the Atomic Energy Agency,

- provincial threat detection and alarm systems,

- provincial early warning systems about threats,

- a system for detecting and alerting of threats and pollution of the marine environment.

Mutual information on threats at different levels of civil-military administration is to enable the society to prepare in advance for defense or sheltering against them, and thus to minimize losses. In this respect, the following alarm signals have been developed to warn the population about threats: about natural disasters and environmental threats, air threats, contamination, contamination warnings, threats of contamination, cancellations of alarms. Signals can be transmitted by means of sirens, radio, television and cable radio stations, bells and gongs. They are to be used only in real emergency situations. On the other hand, the announcement of training and control signals may take place after prior announcement by the mass media 24 hours in advance.

The State Medical Rescue System is an important system in cooperation with institutions for detecting, recognizing, notifying and alarming about contamination and infections ${ }^{36}$. The Minister of Health and Provincial Governors have been made responsible for its organization and preparation, in

\footnotetext{
${ }^{35}$ Regulation of the Council of Ministers of 7 January 2013 on the detection and notification of contaminations and the jurisdiction of authorities in these matters (Journal of Laws, No. 96).

${ }^{36}$ Act of 8 September 2006 on the State Medical Rescue Service (Journal of Laws No. 191, item 1410).
} 
cooperation with hospital rescue units, medical and search rescue teams, and with ${ }^{37}$ : The National Rescue Notification System, the Supreme Medical Council, directors of the appropriate branch of the National Health Fund, trauma centers, organizational units of specialized hospitals, pharmacies, clinics, medical universities, the State Fire Service, The Police, the heads of the Provincial Military Staff, the commanders of the Military Preventive and Therapeutic Districts, the Mountain Volunteer Rescue Service, the Tatra Volunteer Rescue Service, the Water Volunteer Rescue Service, social rescue organizations: The National Council of Medical Rescuers, the Polish Association of Medical Rescuers, the National Union of Medical Rescue Employees, the Polish Center for International Aid Foundation and others.

The aim of the system and the entities cooperating with it is to save human health and life through hazard identification, provision of appropriate life-saving equipment and medicines, transport of persons infected by appropriately equipped medical rescue teams for specialist treatment in hospital emergency wards and to units established by law to provide assistance to the injured.

In view of the variability in the type of threats, the rescue system needs to be highly flexible and actions undertaken by its units should be performed in an integrated manner, using appropriate techniques and equipment necessary in a given crisis situation. Especially helpful in securing mass catastrophes and terrorist attacks.

Rescue units associated in the National Rescue and Fire Extinguishing System cooperate with the State Medical Rescue System ${ }^{38}$. The functioning of the system is supervised by the Minister of the Interior. Coordination and direction of system units at the national level is the responsibility of the Commander-in-Chief of the State Fire Service, who is assisted by the Rescue and Civil Protection Coordination Center, composed of three departments ${ }^{39}$ : operational planning and analysis, operational circuits and international activities, crisis management (CZK) and one section of operational data processing. At the provincial level, the position of rescue coordination is subordinate to the provincial commander of the SFS, at the county/municipal level to the position of management - to the county commander of the SFS. The system brings together fire protection units and other services, inspections, guards, including, among others, specialized medical rescue units, ensuring the continuity of the process of rescuing people in a state of emergency to health or life, and chemical and environmental to identify a chemical agent.

In all this there is a need to develop a (rescue) response plan. During its development it is necessary, inter alia, to develop principles of cooperation between individual rescue entities and cooperating institutions, procedures of cooperation, competence of undertaken actions, principles of organization of joint exercises and analysis of rescue operations, procedures of notification, disposition and coordination of rescue operations in case of events causing a health emergency of a large number of people, circulation and exchange of information ${ }^{40}$. The plan should describe who will do what, what and when, by what means and on what legal basis. This will take place before, during and after the crisis has been brought under control ${ }^{41}$.

\footnotetext{
${ }^{37}$ J. Pilżys, Communication in crisis management and rescue systems in Poland - theory and practice, Szczecin 2015, p. 100-101.

${ }^{38}$ Regulation of the Minister of Internal Affairs and Administration of 3 July 2017 on the detailed organization of the national rescue and firefighting system (Journal of Laws, No. 1319).

${ }^{39}$ E. Kochanek, The role and tasks of the State Fire Service in Crisis Management, [in:] M. Cupryjak, J. Pilżys (ed.) State services, government and local government organizations in the face of challenges of contemporary threats, Szczecin 2014, p. 184.

${ }^{40}$ Regulation of the Minister of Internal Affairs and Administration of 4 July 1992 on the scope and mode of exercising rights by the person in charge of the rescue operation (Journal of Laws No 54, item 259), Regulation of the Minister of Health of 21 December 2010 on the provincial action plan for the national medical rescue system and the criteria for calculating the costs of operation of medical rescue teams (Journal of Laws No 3, item 6), paragraph 2, section 6.

${ }^{41}$ Regulation of the Minister of Health of 23 May 2002 on the procedure of creating county, provincial and national annual medical plans for rescue operations (Journal of Laws No 79, item 721), B. Kosowski, Programming activities in case of emergency situations. Practical Guide, School of Fire Service Operators, Cracow 2006, M. Schroeder, County Rescue Plans, [in:] Z. Sural (ed.) Training of Voluntary Fire Services of the Republic of Poland, Józefów near Otwock 2009, P. Serwatka, Potential of basic rescuing systems, Scientific notebooks of the Witelon State Higher Vocational School, Legnica 2009, No. 9.
} 
Once safety managers have identified where and where an impact may occur, they should start to identify its effects. The measurement of a dangerous event caused by weapons of mass destruction should be based on an analysis of the loss of human life and property in similar incidents that have occurred in the past and in the present. Today, this allows crisis management analysts to draw up a safety net ${ }^{42}$. On the basis of the created (predictable) situation, they try, together with representatives of endangered public facilities (hospitals, schools, power plants, refineries, forest complexes), to predict the risk of occurrence of hazards and their consequences.

The results obtained, constitute the basis for the development of the first part of the crisis management plan, i.e. the master plan, which, in addition to risk assessment and threat characterization, shall include $^{43}$ :

- characterization of forces and assets, including the state of state reserves, and an assessment of their use in the fight against specific threats,

- an analysis of the functioning of public administration, its effectiveness and its capacity to be used in crisis situations,

- the options envisaged for crisis response,

- guidance on how to amend the plan and develop annexes.

Recognizing the effects (consequences) of impacts, in our case, of weapons of mass destruction as well as conventional ones, they will be losses in people and infrastructure. In assessing individual impacts, an account should be taken of the synergy that may exist between them in terms of the sum of their effects. In these cases, we are dealing with a sudden or predicted negative effect, which in the present and future we will have to reduce (eliminate) to a minimum by using appropriate forces and means and methods of action in accordance with the response plans developed for this purpose.

Until now, the threat of using biological weapons against people has been raised. And what about farm animals and wild animals, which can be contaminated by nature, man or aggressor. Is there any system in our country with the strength and resources to control infectious animal diseases? (Fig. 1)

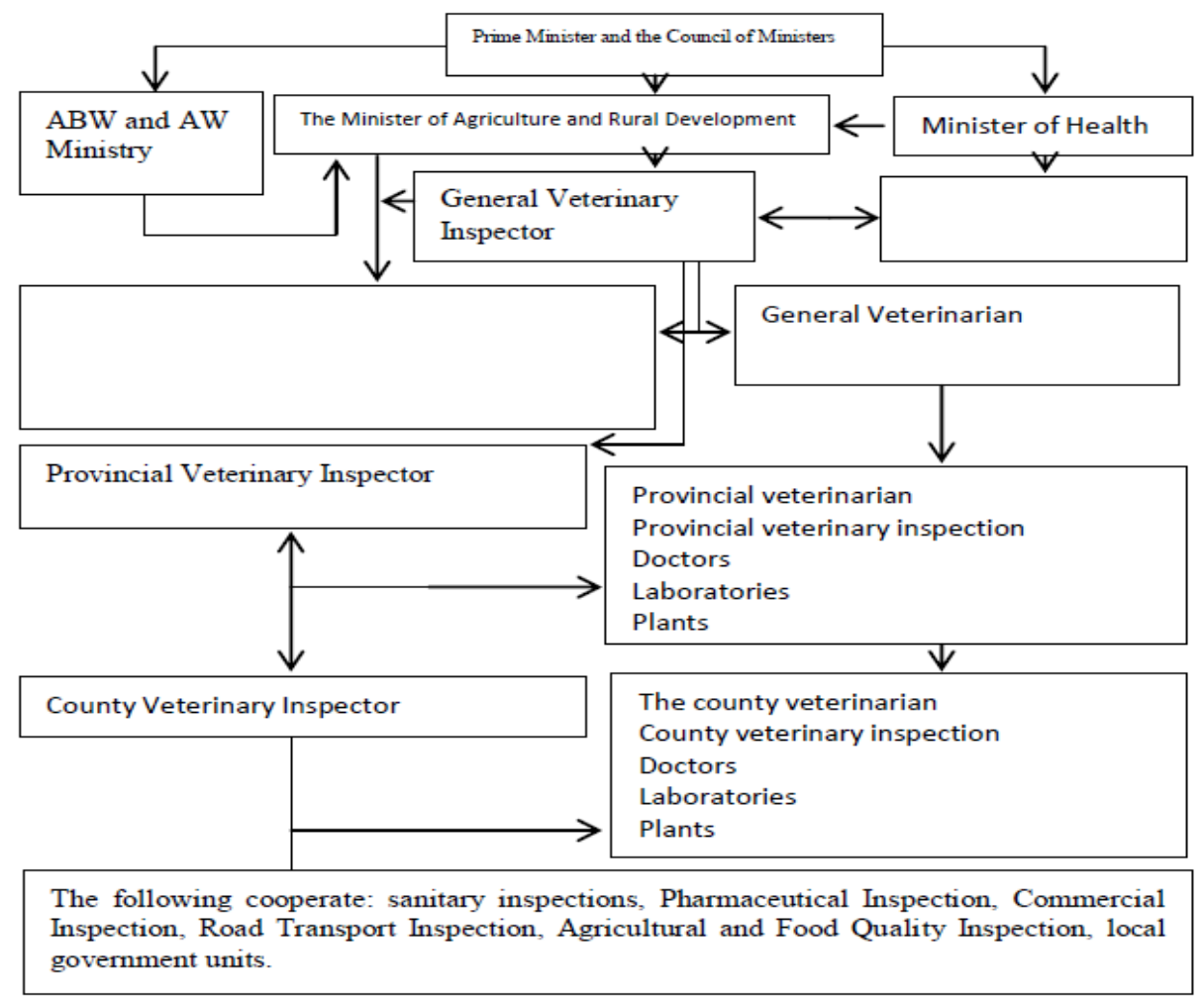

Fig1. Control system for contagious animal diseases

Source: own elaboration

\footnotetext{
${ }^{42}$ It lists the risks that may occur and assigns to each of them institutions that have a leading, ancillary and collaborative role to play.

${ }^{43}$ Act of 26 April 2007 on crisis management (Journal of Laws of 2007, No. 89, item 590), Article 5.2.
} 
In response to the question, at the level of the General Inspectorate of Veterinary Medicine, District and Provincial Veterinary Inspectorates, Preparedness Plans for the Control of Infectious Animal Diseases were prepared. They were based on the integration of several ministries and central offices: Ministry of Health, Ministry of Infrastructure, Ministry of Finance, Ministry of Justice, Ministry of National Education and Sport, Ministry of State Sanitary Inspection, Ministry of National Defense, Ministry of the Interior and Administration, Ministry of Internal Security Agency and Intelligence Agency and other state institutions. The development of such a plan requires ${ }^{44}$ :

- defining the legal standards for the control of infectious animal diseases

- defining the means and the sources of financing for disease control

- the description of the communicable disease

- an analysis of the forces and means of combating the disease

- definition of tasks for government administration bodies and tertiary-level self-government units, as well as for entities possessing adequate material, exchange and technical means to control the disease, the development of an Annex in the form of a communication plan

- the development of a logistical security plan (author's annotation),

- training of staff of institutions responsible for carrying out tasks in each phase of crisis management, i.e. prevention, preparation, response and recovery.

The establishment of such a plan requires the development of appropriate legal bases for the control of communicable diseases (Newcastle disease - ND, communicable fish diseases - ISA, IHN, WHS, swine vesicular disease - SVD, virulent avian influenza - concerning avian disease - HPAI, swine fever - CSF and ASF, foot-and-mouth disease - FMD and others).

In addition, threats from terrorists who use or threaten to use biological or other weapons to achieve their political, religious or ideological objectives by creating fear, intimidation or coercion are a serious security concern ${ }^{45}$. This phenomenon is based on unconventional activities, most often of a criminal nature, the effects of which are to go beyond the direct victims of the attack ${ }^{46}$. They can attack from the air, sea and land using bacteria ${ }^{47}$ : anthrax of the plague, tularemia, brucellosis, $Q$ fever, glanders and melioidosis and cholera, salmonella; viruse ${ }^{48}$ : smallpox, viral haemorrhagic fever, Venezuelan encephalitis, foot-and-mouth disease and biological toxins ${ }^{49}$ in the form of : mycotoxins, fungi, botulism, staphylococcus enterotoxin type B, ricin and saxitoxins, trichothelial mycotoxins and many others that can cause: the spread of microorganisms and their toxins in food, soil, water, in the air in the form of aerosol, fear psychosis, belief in the impossibility of prevention, lack of effective drugs, difficulties in immediate diagnosis of the causes of disease and death, misleading symptoms during the development of the disease.

This threat is often called bioterrorism, i.e. the illegal use of the biological agents mentioned above against people with the intention of forcing some action to be taken in order to achieve one's own goals $^{50}$.

\footnotetext{
${ }^{44}$ Regulation of the Minister of Agriculture and Rural Development of 30 April 2004 on the list of infectious diseases in animals for which contingency plans for their control are drawn up (Journal of Laws No 108, item 1153), paragraph 1, Article 54.

${ }^{45}$ T. R. Aleksandrowicz, International terrorism, Warsaw 2015, p. 27, M. Madej, International Political Terrorism, Warsaw 2001.

46 J. Pilżys, Transnational threats to the national security of the Republic of Poland, [in:] K. Kowalczyk, W. Wróblewski (ed.), Terrorism. Global challenge, Toruń 2006, p. 190.

${ }^{47}$ K. Chomiczewski, J. Kocik, M.T. Pity, Bioterrorism. Principles of medical treatment, Warsaw 2002, p. 190, P. Kępka, Bioterrorism..., p. 44-69, On these pages the author presents numerous divisions of biological agents, see also: K. Langbein, C. Skalnik, I. Smolek, Bioterrorism, Warsaw 2003, M. Prusakowski, Bioterror. How not to get killed, Gdańsk 2001.

${ }^{48}$ E. Croddy, C. Perez-Armendariz, J. Hart, Chemical and biological weapons, Warsaw 2003, p. 262-266.

${ }^{49}$ Ibidem, p. 266-272.

${ }^{50}$ S. Jankowska, Contemporary threats of bioterrorism, [w:] A. Aksamitowski, S. Bylina, M. Cupryjak (ed.) Contemporary terrorism...., p. 196.
} 
In counteracting terrorist threats, including bioterrorism, continuous reconnaissance actions are performed by both civil and military intelligence, in order to obtain information about possible threats, targets of attacks and at the same time help the anti-crisis forces to decide how to neutralize them ${ }^{51}$.

\section{REFERENCES}

[1] Aleksandrowicz T. R., International terrorism, Warsaw 2015.

[2] Balcerowicz B., About peace and war. Between the essay and the treatise, Warsaw 20.

[3] Biniak-Pieróg M., Zamiar Z., Organization of rescue systems, Wrocław 2013.

[4] Bloch J. G., The future war in technical, economic and political terms, Warsaw 2005.

[5] Chocha BKaczmarek., J., War and war doctrine. Selected issues, Warsaw 1980

[6] Chojnowski L., International Security. Institutional and organizational aspects, Słupsk 2017.

[7] Chojnowski L., International security. International and organizational aspects, Słupsk 2017.

[8] Chomiczewski K., Kocik J., Pity M.T., Bioterrorism. Principles of medical treatment, Warsaw 2002.

[9] Croddy E., Perez-Armendariz C., Hart J., Chemical and biological weapons, Warsaw 2003. Data regarding the division of threats and their characteristics were taken from the provincial crisis management plan Łódź and the municipal crisis management plan - Sieradz, [in:] http: // www. lodzkie.eu/data/other/wpzk04. 2012.pdf [read: September 26, 2012].

[10] Defense against Weapons of Mass Destruction, AON, Faculty of Land Forces, Warsaw 2007.

[11] Defense against Weapons of Mass Destruction, Warsaw 2007.

[12] Disarmament, [in:] http://www.unic.un.org.pl/rozbrojenie/konferencja_disqualnic.php [accessed on April 5, 2018].

[13] Enerlich M., Wojtal J., Milewicz M. (ed.), Protection of persons and property, Toruń 2003.

[14] Feluch W., Flood risk forecasting, [in:] Security management at the local level, Warsaw 2012.

[15] Góralczyk W., Sawicki S., Public International Law in outline, Warsaw 2013.

[16] http://www.sieradz.eu/sites/ default / files / plik / uzytkownicy / bbo / urban crisis management_plan 2012-no pelnakopia0.pdf [read: 31 January 2013].

[17] Jakubczak R., Flis J. (ed.), National security of Poland in the 21st century. Challenges and strategies, Warsaw 2006.

[18] Jemioło T., Kubaczyk T., Preus M., Arms of mass destruction in international law - selected problems, Warsaw 2004.

[19] Kępka P., Bioterrorism. Poland in the face of the Use of Biological Weapons, Warsaw 2009.

[20] Kitler W., Protection of population, [in:] W. Kitler (ed.) Non-military civil defense in national defense of the Third Republic of Poland, Warsaw 2001.

[21] Kochanek E., The role and tasks of the State Fire Service in Crisis Management, [in:] M. Cupryjak, J. Pilżys (ed.) State services, government and local government organizations in the face of challenges of contemporary threats, Szczecin 2014.

[22] Kosowski B., Programming activities in case of emergency situations. Practical Guide, School of Fire Service Operators, Cracow 2006,

[23] Kuźnar Z., Barczyk K., The phenomenon of war from the point of view of G.F. Hegel's dialectic philosophy, [in:] M. Bodziany (ed.) Society and war. The face of security in the twentieth and twenty-first centuries, Wrocław 2016.

[24] Madej M., International Political Terrorism, Warsaw 2001.

[25] Makowski A., Marine wars - methodological problems, [w:] A. Aksamitowski, M. Franz (ed.), From the history of the maritime wars. Studies and sketches, Oświęcim 2015.

[26] Miśkiewicz B., War as the subject of historical research, [in:] K. Olejnik (ed.), War as a subject of historical research, Toruń 2006.

[27] Nye J. S. jr.,, International Conflicts. Introduction to Theory and History, Warsaw 2009.

[28] Pilżys J., Communication in crisis management and rescue systems in Poland - theory and practice, Szczecin 2015.

[29] Pilżys J., Lexicon of economic safety, Szczecin 2011.

${ }^{51}$ R. Borkowski, Is Polish society prepared to face the threat of a terrorist attack? K. Kowalczyk, W. Wróblewski (ed.), Terrorism..., p. 194. 
[30] Pilżys J., Selected aspects of threat by toxic industrial agents, [in:] K. Chwesiuk (ed.), Crisis management in land transport in Pomerania, Koszalin 2003.,

[31] Pilżys J., System of security of monuments and national heritage of the Republic of Poland, [in:] J. Piątek, R. Podgórzańska (ed.) Selected aspects of security, Volume I, Szczecin 2007

[32] Pilżys J., Transnational threats to the national security of the Republic of Poland, [in:] K. Kowalczyk, W. Wróblewski (ed.), Terrorism. Global challenge, Torun 2006.

[33] Prusakowski K. M., Bioterror. How not to get killed, Gdańsk 2001.

[34] Regulation of the Minister of Agriculture and Rural Development of 30 April 2004 on the list of infectious diseases in animals for which contingency plans for their control are drawn up (Journal of Laws No 108, item 1153).

[35] Regulation of the Minister of Internal Affairs and Administration of 18 February 2011 on detailed rules of organization of the national rescue and firefighting system (Journal of Laws No. 46, item 239), Appendix 1: The appendix presents methods of threat assessment in the area of the county and the province.

[36] Regulation of the Minister of Internal Affairs and Administration of 18 February 2011 on detailed rules of organization of the national rescue and firefighting system (Journal of Laws of 2011 No 46, item 239).

[37] Regulation of the Minister of Internal Affairs and Administration of 3 July 2017 on the detailed organization of the national rescue and firefighting system (Journal of Laws, No. 1319).

[38] Regulation of the Minister of Internal Affairs and Administration of 4 July 1992 on the scope and mode of exercising rights by the person in charge of the rescue operation (Journal of Laws No 54, item 259),

[39] Ryszka F., Politics and war, colloquial awareness and 20th century theories, State Publishing Institute, Warsaw 1975.

[40] Schroeder M., County Rescue Plans, [in:] Z. Sural (ed.) Training of Voluntary Fire Services of the Republic of Poland, Józefów near Otwock 2009.

[41] Serwatka P., Potential of basic rescuing systems, Scientific notebooks of the Witelon State Higher Vocational School, Legnica 2009.

[42] Śladkowski S., Threats of the battlefield, [in:] Defense against weapons of mass destruction, Warsaw 2007.

[43] Toffler A., Toffler H., War and anti-war, how to survive on the threshold of the 21st century, Warsaw 1997.

[44] Walzer M., Just and unjust wars, Warsaw 2010.

[45] White book on the National Security of the Republic of Poland, Warsaw 2013.

[46] Wróblewski D., Concept of a long-term rescue system, Józefów 2016.

[47] Zubrzycki W., The threat of terrorism to Europe. Selected topics, [in:] A. Aksamitowski, S. Bylina, M. Cupryjak (ed.), Contemporary terrorism. Dimensions of action and effects, Szczecin 2018.

[48] Regulation of the Minister of Health of 23 May 2002 on the procedure of creating county, provincial and national annual medical plans for rescue operations (Journal of Laws No 79, item 721).

[49] Act of 8 September 2006 on the State Medical Rescue Service (Journal of Laws No. 191, item 1410).

[50] Act of 26 April 2007 on crisis management (Journal of Laws of 2007, No. 89, item 590).

[51] Act of 6 September 2008 on the prevention and control of infections and infectious diseases in humans (Journal of Laws No. 234, item 1570).

[52] Regulation of the Minister of Health of 21 December 2010 on the provincial action plan for the national medical rescue system and the criteria for calculating the costs of operation of medical rescue teams (Journal of Laws No 3, item 6).

[53] Regulation of the Council of Ministers of 7 January 2013 on the detection and notification of contaminations and the jurisdiction of authorities in these matters (Journal of Laws, No. 96).

Citation: Dr Jan Pilży. "Characteristics of War Threats (Causes, Effects and Ways to Counteract Them)". International Journal of Humanities Social Sciences and Education (IJHSSE), vol 5, no. 7, 2018, pp. 102-115. doi: http://dx.doi.org/10.20431/2349-0381.0507012.

Copyright: (c) 2018 Authors. This is an open-access article distributed under the terms of the Creative Commons Attribution License, which permits unrestricted use, distribution, and reproduction in any medium, provided the original author and source are credited. 